\title{
Behavior Pattern of Individual Investors in Stock Market
}

\author{
Luu Thi Bich Ngoc ${ }^{1}$ \\ ${ }^{1}$ Vietnam Datacommunication Company 2 (VDC2), Open University, Ho Chi Minh City, VietnamVietnam \\ Correspondence: Luu Thi Bich Ngoc, 386 Dien Bien Phu Street, Ward 17, Binh Thanh District, Ho Chi Minh \\ City, Vietnam. E-mail: luungoc@hotmail.com
}

Received: June 13, 2013

Accepted: September 13, 2013

Online Published: December 15, 2013

doi:10.5539/ijbm.v9n1p1

URL: http://dx.doi.org/10.5539/ijbm.v9n1p1

\begin{abstract}
This research aims to investigate behavioral factors influencing the decisions of individual investors at the Securities Companies in Ho Chi Minh City, Vietnam. Data for this research was collated from 188 responses from individual investors, accounting for the response rate of $63 \%$. There are five behavioral factors of individual investors at the Ho Chi Minh Stock Exchange: Herding, Market, Prospect, Overconfidence-gamble's fallacy, and Anchoring-ability bias. Securities Companies may also use the findings of this research for better understanding on investors' decision to give better recommendations to them. Stock prices then reflect their true value and Ho Chi Minh stock market becomes the yardstick of the economy's wealth and helps enterprises to raise capital for business activities.
\end{abstract}

Keywords: individual investor, behavior pattern, stock market, Vietnam

\section{Introduction}

Stock market is a market where stocks are bought and sold (Zuravicky, 2005, p. 6; Luu, 2011). In an economy, besides playing the role of a source for financing investment, stock market also performs a function as a signaling mechanism to managers regarding investment decisions, and a catalyst for corporate governance (Samuel, 1996, p. 1). However, stock market is best known for being the most effective channel for company's capital raise (Zuravicky, 2005, p. 6). People are interested in stock because of "long-term growth of capital, dividends, and a hedge against the inflationary erosion of purchasing power" (Teweles \& Bradley, 1998, p. 8). The other feature that makes the stock market more attractive than other types of investment is its liquidity (Jaswani, 2008). Most people invest in stocks because they want to be the owners of the firm, from which they benefit when the company pays dividends or when stock prices increases (Croushore, 2006, p. 186). However, many people buy stocks for the purpose of control over the firms. Regularly, shareholders need to own specific amount of shares to be in the board of directors who can make strategic decisions and set directions for the firms. Vietnamese stock market has come into operation more than 10 years. It was just develop slowly from the speculative bubble in 2006-2007. The VN-index had an amazing fluctuation from 2006 to 2009. It was about 300 points and reached highest historical peak (over 1100) points of VN-index in March 2007, then after the stock bubble burst in $2008 \mathrm{VN}$-index fell around 250-300 points at beginning of 2009 and VN-index is still around 350 points in 2011 (Vuong, 2011). The stock prices declined dramatically which was consequence of moving capital from stock market to the real estate market and caused withdrawal of numerous investors as the manifestation of effect of behavioral factors on investors' decisions and reactions.

To have an indepth insight into the investors' decisions, there is a necessity to investigate which behavioral factors influencing the decisions of individual investors at the Securities Companies in Ho Chi Minh City. It will be useful for investors to understand common behaviors, from which justify their reactions for better returns. Securities Companies may also use the finding of this research for better understanding on investors' decision to give better recommendations to them. Thus, stock prices will reflect their true value and Ho Chi Minh stock market becomes the yardstick of the economy's wealth and helps enterprises to raise capital for business activities. The research needs to answer the following question:

What is the behavior of individual investors in Vietnamese stock market? 


\section{Literature Review}

\subsection{Definition on Behavior Finance}

"Behavior of investor is a part of behavior finance, which seeks to understand and predict systematic financial market implications of psychological decision processes. Behavior finance closely combines individual behavior and market phenomena and uses knowledge taken from both the psychological field and financial theory." (Fromlet, 2001).

\subsection{Theories and Factors of Behavior Finance}

\subsubsection{The Prospect Theory}

"Prospect theory, which was developed by Kahneman and Tversky (1979), is one of the most often quoted and best-documented phenomena in economic psychology. The theory states that we have an irrational tendency to be less willing to gamble with profits than with losses." Tvede $(1999$, p. 166) prospect theory showed human behavior when they face with risk and uncertainly. In particular, people are prone to certainly, therefore people overweight on the outcomes that are perceived more certain than that are considered mere probable. This called certainly effect that human beings are not consistently risk-averse; rather they are risk-averse in gains but risk-takers in losses (Kishore, 2004). In other words, traders are most inclined to take subsequent risks if they have already experienced losses. By contrast, trader who have experienced profit, usually their exposure to the next risk. Therefore, people respond differently, depending on whether the choices are framed in terms of gains or in term of losses. The most famous example of framing effects was illustrated by Tversky and Kahneman (1981).

Expected Utility Theory (EUT) and prospect theory are considered as two approaches to decision-making from different perspectives. Prospect theory focuses on subjective decision-making influenced by the investors' value system, whereas EUT concentrates on investors' rational expectations (Filbeck, Hatfield \& Horvath, 2005, p. 170-171). EUT is the normative model of rational choice and descriptive model of economic behavior, which dominates the analysis of decision making under risk. Nonetheless, this theory is criticized for failing to explain why people are attracted to both insurance and gambling. People tend to under-weigh probable outcomes compared with certain ones and people response differently to the similar situations depending on the context of losses or gains in which they are presented (Kahneman \& Tversky, 1979, p. 263). Prospect theory describes some states of mind affecting an individual's decision-making processes including Regret aversion, Loss aversion and Mental accounting (Waweru et al., 2003, p. 28). Regret is an emotion occurs after people make mistakes. Investors avoid regret by refusing to sell decreasing shares and willing to sell increasing ones. Moreover, investors tend to be more regretful about holding losing stocks too long than selling winning ones too soon (Forgel \& Berry, 2006, p. 107; Lehenkari \& Perttunen, 2004, p. 116).

Loss aversion refers to the difference level of mental penalty people have from a similar size loss or gain (Barberis \& Huang, 2001, p. 1248). There is evidence showing that people are more distressed at the prospect of losses than they are pleased by equivalent gains (Barberis \& Thaler, 2003, p. 1077). Moreover, a loss coming after prior gain is proved less painful than usual while a loss arriving after a loss seems to be more painful than usual (Barberis \& Huang, 2001, p. 1248). In addition, Lehenkari and Perttunen (2004, p. 116) find that both positive and negative returns in the past can boost the negative relationship between the selling trend and capital losses of investors, suggesting that investors are loss averse. Risk aversion can be understood as a common behavior of investor, nevertheless it may result in bad decision affecting investor's wealth (Odean, 1998a, p. 1899).

Mental accounting is a term referring to "the process by which people think about and evaluate their financial transactions" (Barberis \& Huang, 2001, p. 1248). Mental accounting allows investors to organize their portfolio into separate accounts (Barberis \& Thaler, 2003, p. 1108; Ritter, 2003, p. 431). From own empirical study, Rockenbach (2004, p. 524) suggests that connection between different investment possibilities is often not made as it is useful for arbitrage free pricing.

An important thing is that prospect theory is suggested an alternative model of expected utility theory following Von Neumann Morgenstern rationality. It differs from expected utility theory in a number of important respects. First, the value maximization the function of the prospect theory is value which is different from that of the value maximization function of expected utility theory is utility (Plous, 1993). This mean whereas wealth maximization of the prospect theory is values between gains and losses, rather than over the final wealth position as in expected utility theory. Moreover, the value function is normally concave for gains, commonly convex for losses, and is generally steeper for losses than for gains (Kahneman \& Tversky, 1979). These 
differences lead to several noteworthy results. Plous (1993) noted that because the value function for losses is steeper than that for gains, losses or loom larger than gains. For instance, a loss of 500 is felt more than a gain of 500 .

\subsubsection{Heuristics Theory}

Heuristics are defined as the rules of thumb, which makes decision making easier, especially in complex and uncertain environments (Ritter, 2003, p. 431) by reducing the complexity of assessing probabilities and predicting values to simpler judgments (Kahneman \& Tversky, 1974, p. 1124). In general, these heuristics are quite useful, particularly when time is limited (Waweru et al., 2008, p. 27), but sometimes they lead to biases (Kahneman \& Tversky, 1974, p. 1124; Ritter, 2003, p. 431). Kahneman and Tversky seem to be ones of the first writers studying the factors belonging to heuristics when introducing three factors namely representativeness, availability bias, and anchoring (Kahneman \& Tversky, 1974, pp. 1124-1131). Waweru et al. also list two factors named Gambler's fallacy and Overconfidence into heuristic theory (Waweru et al., 2008, p. 27).

Representativeness refers to the degree of similarity that an event has with its parent population (DeBondt \& Thaler, 1995, p. 390) or the degree to which an event resembles its population (Kahneman \& Tversky, 1974, p. 1124). Representativeness may result in some biases such as people put too much weight on recent experience and ignore the average long-term rate (Ritter, 2003, p. 432). A typical example for this bias is that investors often infer a company's high long-term growth rate after some quarters of increasing (Waweru et al., 2008, p. 27). Representativeness also leads to the so-called "sample size neglect" which occurs when people try to infer from too few samples (Barberis \& Thaler, 2003, p. 1065). In stock market, when investors seek to buy "hot" stocks instead of poorly performed ones, this means that representativeness is applied. This behavior is an explanation for investor overreaction (DeBondt \& Thaler, 1995, p. 390).

The belief that a small sample can resemble the parent population from which it is drawn is known as the "law of small numbers" (Rabin, 2002, p. 775; Statman, 1999, p. 20) which may lead to a Gamblers' fallacy (Barberis \& Thaler, 2003, p. 1065). More specifically, in stock market, Gamblers' fallacy arises when people predict inaccurately the reverse points which are considered as the end of good (or poor) market returns (Waweru et al., 2008 , p. 27). In addition, when people subject to status quo bias, they tend to select suboptimal alternative simply because it was chosen previously (Kempf \& Ruenzi, 2006, p. 204).

Anchoring is a phenomena used in the situation when people use some initial values to make estimation, which are biased toward the initial ones as different starting points yield different estimates (Kahneman \& Tversky, 1974, p. 1128). In financial market, anchoring arises when a value scale is fixed by recent observations. Investors always refer to the initial purchase price when selling or analyzing. Thus, today prices are often determined by those of the past. Anchoring makes investors to define a range for a share price or company's income based on the historical trends, resulting in under-reaction to unexpected changes. Anchoring has some connection with representativeness as it also reflects that people often focus on recent experience and tend to be more optimistic when the market rises and more pessimistic when the market falls (Waweru et al., 2008, p. 28).

When people overestimate the reliability of their knowledge and skills, it is the manifestation of overconfidence (DeBondt \& Thaler, 1995, p. 389, Hvide, 2002, p. 15). Many studies show that excessive trading is one effect of investors. There is evidence showing that financial analysts revise their assessment of a company slowly, even in case there is a strong indication proving that assessment is no longer correct. Investors and analysts are often overconfident in areas that they have knowledge (Evans, 2006, p. 20).

Overconfidence is believed to improve persistence and determination, mental facility, and risk tolerance. In other words, overconfidence can help to promote professional performance. It is also noted that overconfidence can enhance other's perception of one's abilities, which may help to achieve faster promotion and greater investment duration (Oberlechner \& Osler, 2004, p. 3). If an investor overestimates his ability to generate information or to identify the significance of existing data that others neglect, he will underestimate his forecast errors; he will tend to be overconfident about the information he has generated but not about public signals. Thus the person who overestimates the precision of his own information signal instead of received publicly information signals is defined as an overconfident investors. The author of the above statement is Kent Daniel, David Hirshleifer and Avanidhar Subramanian (1998). People tend to think that they are better than they really are (Trivers, 1991). Both the psychology and the recent finance literature characterize people with this type of behavior as being "overconfident." Studies in human behavior have shown that overconfidence is a major contributing factor to overtrading phenomenon of financial market participants. Barber and Odean (1999) attributed the high volume of trading to investors 'overconfidence, in which makes investors believe their own judgment too definitely and not enough consider others' assessment. The role of overconfidence in the trading 
tendency of stock has been studied by Grinblatt and Keloharju (2006). They analyzed and found that overconfident investors tend to trade more frequently.

Availability bias happens when people make use of easily available information excessively. In stock trading area, this bias manifest itself through the preference of investing in local companies which investors are familiar with or easily obtain information, despite the fundamental principles so-called diversification of portfolio management for optimization (Waweru et al., 2003, p. 28).

\subsubsection{Market Factor}

DeBondt and Thaler (1995, p. 396) state that financial markets can be affected by investors' behaviors in the way of behavioral finance. If the perspectives of behavioral finance are correct, it is believed that the investors may have over- or under-reaction to price changes or news; extrapolation of past trends into the future; a lack of attention to fundamentals underlying a stock; the focus on popular stocks and seasonal price cycles. These market factors, in turns, influence the decision making of investors in the stock market. Waweru et al. (2008, p. 36) identifies the factors of market that have impact on investors' decision making: Price changes, market information, past trends of stocks, customer preference, over-reaction to price changes, and fundamentals of underlying stocks.

Market efficiency (Luu, 2012a), in the sense that market prices reflect fundamental market characteristic and that excess returns on the average are leveled out in the long run, have been challenged by behavior finance. There have been the numbers of studies pointing to market anomalies that cannot be explained with the help of standard financial theory, such as abnormal price movements in connection with IPOs, mergers, stock splits and spin-off. Throughout the 1980s and 1990s statistical anomalies have continued to appear which suggests that the existing standard finance models are, if not wrong, probably incomplete. Investors have been shown not to react logically to new information but to be overconfident and to alter their choices when given superficial changes in the presentation of investment information (Olsen, 1998). During the few years there has, for example, been a media interest in technology stocks. Most of the time, as we know in retrospect, there was a positive bias in media assessments, which might have lead investors in making incorrect investment decisions. These anomalies suggest that the underlying principles of rational behavior underlying the efficient market hypothesis are not entirely correct and that we need to look, as well, at other models of human behavior, as have been studies in other social sciences (Shiller, 1998).

Normally, changes in market information, fundamentals of the underlying stock and stock price can cause over/under-reaction to the price change. These changes are empirically proved to have the high influence on decision-making behavior of investors. Researchers convince that over-reaction (DeBondt \& Thaler, 1985, p. 804) or under-reaction (Lai, 2001, p. 215) to news may result in different trading strategies by investors and hence influence their investment decisions. Waweru et al. (2008, p. 36) conclude that market information has very high impact on making decision of investors and this makes the investors, in some way, tend to focus on popular stocks and other attention-grabbing events that are relied on the stock market information. Moreover, Barber and Odean (2000, p. 800) emphasize that investors are impacted by events in the stock market which grab their attention, even when they do not know if these events can result good future investment performance. Odean (1998a, p. 1887) explores that many investors trade too much due to their overconfidence.

These investors totally rely on the information quality of the market or stocks that they have when making decisions of investment. Waweru et al. (2008, p. 37) indicate that price change of stocks has impact on their investment behavior at some level. Odean $(1999$, p. 1292) states that investors prefer buying to selling stocks that experience higher price changes during the past two years. Change in stock price in this context can be considered as an attention-grabbing occurrence in the market by investors. Additionally, Caparrelli et al. (2004, p. 223) propose that investors are impacted by herding effect and tend to move in the same flow with the others when price changes happen. Besides, investors may revise incorrectly estimates of stock returns to deal with the price changes so that this affects their investment decision-making (Waweru et al., 2008, p. 37).

Many investors tend to focus on popular stocks or hot stocks in the market (Waweru et al., 2008, p. 37). Odean (1999, p. 1296) proposes that investors usually choose the stocks that attract their attention. Besides, the stock selection also depends on the investors' preferences. Momentum investors may prefer stocks that have good recent performance while rational investors tend to sell the past losers and this may help them to postpone taxes. In contrast, behavioral investors prefer selling their past winners to postpone the regret related to a loss that they can meet for their stock trading decisions (Waweru et al., 2008, p. 30). Besides, past trends of stocks are also explored to impact the decision making behavior of the investors at a certain level by Waweru et al. (2008, p. 37). In this concept, investors usually analyze the past trends of stocks by technical analysis methods before 
deciding an investment.

In general, market factors are not included in behavioral factors because they are external factors influencing investors' behaviors. However, the market factors influence the behavioral investors (as mentioned above) and rational investors in different ways, so that it is not adequate if market factors are not listed when considering the behavioral factors impacting the investment decisions. Together with the research of Waweru et al. (2008), this research treats the market factors fairly as behavioral factors influencing the decisions of investors in the stock market.

\subsubsection{Herding Effect}

Herding effect in financial market is identified as tendency of investors' behaviors to follow the others' actions. Practitioners usually consider carefully the existence of herding, due to the fact that investors rely on collective information more than private information can result the price deviation of the securities from fundamental value; therefore, many good chances for investment at the present can be impacted. Academic researchers also pay their attention to herding; because its impacts on stock price changes can influence the attributes of risk and return models and this has impacts on the viewpoints of asset pricing theories (Tan, Chiang, Mason \& Nelling, 2008, p. 61). In the perspective of behavior, herding can cause some emotional biases, including conformity, congruity and cognitive conflict, the home bias and gossip. Investors may prefer herding if they believe that herding can help them to extract useful and reliable information. Whereas, the performances of financial professionals, for example, fund managers, or financial analysts, are usually evaluated by subjectively periodic assessment on a relative base and the comparison to their peers. In this case, herding can contribute to the evaluation of professional performance because low-ability ones may mimic the behavior of their high-ability peers in order to develop their professional reputation (Kallinterakis, Munir \& Markovic, 2010, p. 306).

In the security market, herding investors base their investment decisions on the masses' decisions of buying or selling stocks. In contrast, informed and rational investors usually ignore following the flow of masses, and this makes the market efficient. Herding, in the opposite, causes a state of inefficient market, which is usually recognized by speculative bubbles. In general, herding investors act the same ways as prehistoric men who had a little knowledge and information of the surrounding environment and gathered in groups to support each other and get safety (Caparrelli et al., 2004, p. 223). There are several elements that impact the herding behavior of an investor, for example: overconfidence, volume of investment, and so on. The more confident the investors are, the more they rely on their private information for the investment decisions. In this case, investors seem to be less interested in herding behaviors. When the investors put a large amount of capital into their investment, they tend to follow the others' actions to reduce the risks, at least in the way they feel. Besides, the preference of herding also depends on types of investors, for example, individual investors have tendency to follow the crowds in making investment decision more than institutional investors (Goodfellow, Bohl \& Gebka, 2009, p. 213).

Waweru et al. (2008, p. 31) propose that herding can drive stock trading and create the momentum for stock trading. However, the impact of herding can break down when it reaches a certain level because the cost to follow the herd may increase to get the increasing abnormal returns. Waweru et al. (2008, p. 37) identify stock investment decisions that an investor can be impacted by the others: buying, selling, choice of stock, length of time to hold stock, and volume of stock to trade. Waweru et al. conclude that buying and selling decisions of an investor are significantly impacted by others' decisions, and herding behavior helps investors to have a sense of regret aversion for their decisions. For other decisions: choice of stock, length of time to hold stock, and volume of stock to trade, investors seem to be less impacted by herding behavior. However, these conclusions are given to the case of institutional investors; thus, the result can be different in the case of individual investors because, as mentioned above, individuals tend to herd in their investment more than institutional investors.

Previous studies report that investors decrease the selling decisions of assets that get a loss in comparison to the initial purchasing price, a trend called the "disposition effect" by Shefrin and Statman (1985, p. 778). Odean (1998b, p. 1795) confirms the same conclusion that individual investors tend to sell stocks which their values, in comparison to their original buying price, increase rather than sell the decreasing stocks. However, it is difficult to demonstrate this phenomenon in the rational ground. It is not really reasonable to conclude that investors rationally sell winning stocks because they can foresee their poor performance. Besides, Odean also recognizes that the average return of sold stocks is greater than that of the average return of stocks that investors hold on. Genesove and Mayer (2001, p. 19) state that investors who sell their assets at the price less than original purchase price usually expect the selling price is more than other sellers' asking price. It is not only the expectation of the sellers, but also the correction of market decides the selling price: investors encountering a 
loss often do the transaction at the relatively higher price than others. Coval and Shumway (2000, p. 3) find that investors, according to prospect theory, having gains (losses) in the first half of trading day tend to take less (more) risk in the second half of trading day. Grinblatt and Han (2001, p. 1) claim that the behavior of investors which is described as the disposition effect can be considered as a puzzling characteristic of the cross-section of average returns, called momentum in stock returns. In which, investors prefer selling a stock that has helped them to gain capital.

The selling pressure can firstly slow down the stock price, and then create higher returns. In contrast, if the stockholders are experiencing capital losses, they may merely make decision of selling when an expected price is given. In this case, the price may be initially increased, leading to lower returns later.

Odean (1999, p. 1293) provides several understandings about the preferable stocks that individual investors would like to buy. As mentioned above, selling decisions mainly prioritize winning stocks; whereas, buying decisions are related to both prior winning and losing stocks. Odean states that the buying decisions may be a result of an attention effect.

When making a decision of stock purchase, people may not find a good stock to buy after considering systematically the thousands of listed securities. They normally buy a stock having caught their interest and maybe the greatest source for attention is from the tremendous past performance, even good or bad.

According to Barberis and Thaler (2003, p. 1103), individual investors seem to be less impacted by attention-grasping stock for their selling decisions because the selling decision and the buying decision are differently run. Because of short-sale restraints, when deciding to choose a stock for selling, they can only focus on the stocks that currently belong to them. Whereas, with a buying decision, individuals have a lot of chances to choose the wanted stocks from the wide range of selective sources, this explains why factors of attention impact more on the stock buying decisions than the selling decisions.

Barber and Odean $(2002$, p. 2) already prove that the selling decisions are less determined by attention than buying decisions in case of individual investors. To give this conclusion, they create the menu of attention-grasping stocks with several criteria: unusually high trading volume stocks, abnormally high or low return stocks, and stocks including news announcements. Eventually, the authors explore that the individual investors in their sample are more interested in purchasing these high-attention stocks than selling them. As such, from the viewpoints of behavioral finance, the investor behaviors impact both selling and buying decisions at different levels, and then they also impact the general returns of the market as well as the investment performance of individuals.

As mentioned in the literature review above, it is that behavioral factors impact the investment decisions of investors in the financial markets, especially in the stock markets. This study explores the influence levels of the behavioral variables on the individual investors' decisions and at the Ho Chi Minh stock market, as in the following research model.

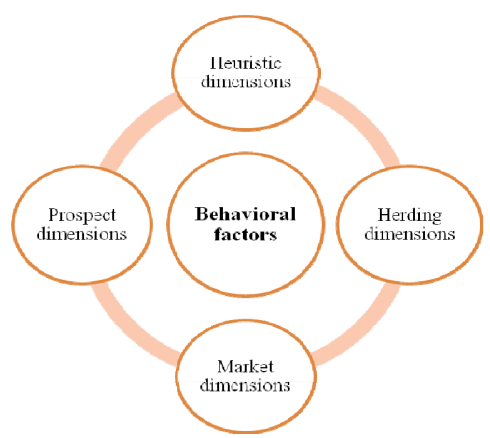

Figure 1. The research model of behavioral factors of individual investors

\section{Research Methodology}

\subsection{Research Method}

In general, theory is built and tested based on two different approaches: induction and deduction. When deductive approach is employed, researchers start with the existing theory and logical relationships among concepts, and then continue to find empirical evidences. In contrast, in inductive research, theory is developed 
from the observations of empirical reality and researchers infer the implications of the findings for the theory that prompted the research (Ghauri \& Gronhaug, 2010, p. 15-16; Saunder et al., 2009, p. 124-126; Blumberg et al., 2005, p. 22-24; Bryman \& Bell, 2007, p. 11).

In this research, exploring the behavioral factors influencing the decision making of investors, which are already "out there", is the main aim, instead of inferring and building theory, deduction approach seems to be the most appropriate choice. The study starts with reviewing the behavioral finance theories in general and in stock market in particular, to get the theoretical and conceptual context as well as empirical findings of previous researches, from which the research model is proposed. Then, the questions used in questionnaires are prepared. This process is quite consistent with deductive approach which emphasizes that researchers may know how the world operates, thus using this approach to examine these ideas against "hard data" (Neuman \& Kreuger, 2003, p. 53). Deductive approach is usually associated with quantitative researches, which involve collecting of quantitative or quantifiable qualitative data and analyzing statistical methods, which is also compatible with quantitative research strategies (Bryman \& Bell, 2007, p. 11-13) albeite the quantitative approach used in this emprical research does not allow for an analysis of the deepest level of the constructs (Luu, 2011; Luu, 2012b; Luu, 2013a; Luu, 2013b; Luu, 2013c).

\subsection{Sample}

As the research aims at exploring the behavioral factors at the HOSE, a relative large sample size is recommended. The larger sample size is, the more representative it can be, thus, the more reliable result is (Saunders et al., 2009, p. 219). Nevertheless, the sample size depends on researchers' available resources including time, finance and human (Saunders et al., 2009, p. 212). Hair, Black, Babin, Andersion and Tatham (1998, p. 111) suggest that with quantitative research, at least 100 respondents should be studied in order to have fit the statistical methods of data analysis.

Questionnaires were delivered directly to individual investors. The security companies are randomly chosen among all the security companies in Ho Chi Minh City. From 300 questionnaires were sent to individual investors. 188 responses in complete forms were returned, accounting for the response rate of $63 \%$, a moderate high rate for a postal questionnaire survey (Luu, 2010; Luu, 2011; Luu, 2013d).

\subsection{Instrument}

The 18-item questionnaire in Vietnamese version were based on the theories of behavioral finance: Heuristic theory, Prospect theory, and other theories about impacts of behavioral factors on investors' decision-making, as highlighted in Waweru et al. (2008, p. 24-38). The 6-point Likert scale, which are rating scale widely used for asking respondents' opinions and attitudes (Fisher, 2010, p. 214), is utilized to ask the individual investors to evaluate the degrees of their agreement with the impacts of behavioral factors on their investment decision as well as with the statements of investment performance. The 6 points in the scale are respectively from 1 to 6 : extremely disagree, highly disagree, somewhat disagree, somewhat agree, highly agree, and extremely agree, the dimensions of the questionnaire are displayed in Table 1.

Table 1. Dimensions of individual investor' behavior

\begin{tabular}{lll}
\hline Dimensions & Behavioral factor & Questions \\
\hline \multirow{3}{*}{ Heuristic } & Representativeness & Questions 1-2 \\
& Overconfidence & Question 3 \\
& Anchoring & Questions 4-5 \\
& Loss aversion & Questions 6-7 \\
Prospect & Regret aversion & Questions 8-9 \\
& Mental accounting & Question 10 \\
& Prices change & Question 11 \\
& Over-reaction & Question 12 \\
& Market information & Question 13 \\
& Past trend of stock & Question 14 \\
& Customer preference & Question 15 \\
& Following the others' & \\
& trading actions (buying and selling, \\
& choice of stock, volume of stock, & Questions 16-18 \\
& and speed of herding) & \\
\hline \multirow{2}{*}{ Herding } & &
\end{tabular}


Data for this study was primary collected through a survey in form of a questionnaire. Primary data refers to data, which is collected for a specific purpose and which is required in order to complement secondary data (Wiedersheim-Paul \& Eriksson, 1997). Self-completion questionnaire seems to be one of the most common methods of quantitative researches. With a self-completion questionnaire, respondents answer questions by completing the questionnaire themselves. This method is chosen for some reasons. The first reason is that as the research questions are defined clearly, questionnaire is the best choice to have standardized data, which is easily to process, and analyze. Especially, as no interviewers are present when the questionnaires are completing, the results may not be affected by the interviewers (Bryman \& Bell, 2007, p. 241). Moreover, it is cheaper than other methods (Bryman \& Bell, 2007, p. 241). Furthermore, this method helps to save time (Bryman \& Bell, 2007 , p. 241) so hundreds questionnaires can be sent out in one batch. As the respondents are investors, they may not have much time for interviews, thus, questionnaires may make them feel more comfortable because they can do it whenever they have free time. Questionnaires also are more convenient for respondents in case they need to provide some sensitive information, in other words; they tend to be more honest than in an interview (Bryman \& Bell, 2007, p. 242).

\subsection{Data Analysis Method}

In this research, the collected data were processed and analyzed by SPSS software. At first, the data were cleaned by removing the questionnaire with poor quality such as including too many missing values or bias ratings. Then, statistical techniques include Factor Analysis, and Cronbach's Alpha test. The reliability of each construct and its specific dimensions was appraised using Cronbach's a coefficients (Luu, 2010; Luu, 2012a).

\section{Findings and Discussion}

\subsection{Factor Analysis of Behavioral Variables Influencing the Individual Investor}

The questions from 1 through 18 of the questionnaire, which are coded from X1 to X18, are designed to explore the levels of behavioral dimensions' impacts on the individual investment decisions at the HOSE (Luu, 2011). The exploratory factor analysis (EFA) is used for the behavioral variables (X1 to X18) to identify the factors which these dimensions belong to. After some rounds of removing the unsuitable variables including (X1, X2, $\mathrm{X} 4, \mathrm{X} 6, \mathrm{X} 9, \mathrm{X} 12, \mathrm{X} 15)$, the analysis results that the remaining dimensions are grouped into five factors of behavioral dimensions, at the Eigenvalue $=1.107, \mathrm{KMO}=0.746(\mathrm{sig} .=0.000), \%$ of total dimension explained $=61.11 \%$, and all factors loadings are more than 0.5 . These indexes prove that factor analysis for these dimensions is totally suitable and accepted. The result is presented in the Table 2.

Table 2. Factor analysis

\begin{tabular}{|c|c|c|c|c|c|c|}
\hline \multirow{2}{*}{ Factors } & \multirow{2}{*}{ Questions } & \multicolumn{5}{|c|}{ Factor loading } \\
\hline & & $\mathrm{F} 1$ & F2 & F3 & $\mathrm{F} 4$ & F5 \\
\hline \multirow[t]{3}{*}{ Herding } & $\begin{array}{l}\text { X16: Other investors' decisions of the stock } \\
\text { volume have impact on your investment } \\
\text { decisions. }\end{array}$ & .854 & & & & \\
\hline & $\begin{array}{l}\text { X17: Other investors' decisions of buying and } \\
\text { selling stocks have impact on your investment } \\
\text { decisions. }\end{array}$ & .873 & & & & \\
\hline & $\begin{array}{l}\text { X18: You usually react quickly to the changes } \\
\text { of other investors' decisions and follow their } \\
\text { reactions to the stock market. }\end{array}$ & .697 & & & & \\
\hline \multirow[t]{3}{*}{ Prospect } & $\begin{array}{l}\text { X7: After a prior loss, you become more risk } \\
\text { averse. }\end{array}$ & & & .862 & & \\
\hline & $\begin{array}{l}\text { X8: You avoid selling shares that have } \\
\text { decreased in value and readily sell shares that } \\
\text { have increased in value. }\end{array}$ & & & .505 & & \\
\hline & $\begin{array}{l}\text { X10: You tend to treat each element of your } \\
\text { investment portfolio separately. }\end{array}$ & & & .826 & & \\
\hline \multirow[t]{2}{*}{ Market } & $\begin{array}{l}\text { X11: You consider carefully the price changes } \\
\text { of stocks that you intend to invest in. }\end{array}$ & & & . & .794 & \\
\hline & $\begin{array}{l}\text { X13: Market information is important for your } \\
\text { stock investment. }\end{array}$ & & & & .773 & \\
\hline
\end{tabular}




\begin{tabular}{ll}
\hline & X14; You put the past trends of stocks under \\
& your consideration for your investment. \\
& X3: You believe that your skills and knowledge \\
& of stock market can help you to outperform the \\
Overconfident & market. \\
& X5: You forecast the changes in stock prices in \\
Anchoring & the future based on the recent stock prices.
\end{tabular}

As shown in the Table 2, there are five behavioral factors that impact on the individual investors at the Ho Chi Minh Stock Exchange. In the herding factor, all three original dimensions from the questionnaire (questions from 16 to 18 which are coded as X16 to X18) are kept after the factor analysis. Three items of market (questions 11, 13,14) and three prospect items (questions $7,8,10$ ) are accepted by factor analysis. Whereas, only two dimensions of heuristic (questions 3, 5) after the analysis and are divided into two groups: overconfidence-gamble's fallacy and anchoring-ability bias.

This finding has just a little difference from the literature review, which expects that the behavioral variables are theoretically formed into four groups: herding, prospect, market, and heuristic. It means four factors as the reviewed theories: Heuristics, Prospect, Market, and Herding are tested by exploratory factor analysis to identify which dimensions the behavioral variables belong to.

\subsection{Cronbach's Alpha Test for Items of Factors}

This test is conducted to ensure that the measurements are reliable for further. The results of Cronbach's alpha test are shown in the Table 3.

Table 3. Cronbach's Alpha test for items of factors

\begin{tabular}{|c|c|c|c|c|c|}
\hline Factors & Variables & Cronbach's Alpha & $\begin{array}{l}\text { Corrected } \\
\text { Item-total } \\
\text { Correlation }\end{array}$ & $\begin{array}{l}\text { Cronbach's alpha } \\
\text { if Item deleted }\end{array}$ & F(sig.) \\
\hline Overconfident & $\mathrm{X} 3$ & .63 & .39 & - & $52(0.000)$ \\
\hline \multirow[t]{2}{*}{ Anchoring } & $\mathrm{X} 5$ & .61 & .36 & - & $16(0.000)$ \\
\hline & $\mathrm{X} 7$ & .63 & .44 & .54 & $21(0.000)$ \\
\hline \multirow[t]{3}{*}{ Prospect } & $\mathrm{X} 8$ & & .39 & .57 & \\
\hline & $\mathrm{X} 10$ & & .49 & .51 & \\
\hline & X11 & .74 & .55 & .65 & $2(0.05)$ \\
\hline \multirow[t]{3}{*}{ Market } & $\mathrm{X} 13$ & & .56 & .64 & \\
\hline & X14 & & .55 & .65 & \\
\hline & $\mathrm{X} 16$ & .88 & .77 & .79 & $24(0.000)$ \\
\hline \multirow[t]{2}{*}{ Herding } & $\mathrm{X} 17$ & & .72 & .81 & \\
\hline & X18 & & .60 & .79 & \\
\hline
\end{tabular}

Table 3 presents that Cronbach's Alpha indexes of all factors are greater 0.6, and the corrected item-total correlation of all items are more than 0.30. Besides, Cronbach's alpha of each factor if deleted is less than the factor's Cronbach's Alpha, as well as the significant of $F$ test for each factor, a kind of test to make sure the suitability of using Cronbach's Alpha technique for the data, is less than 0.05 . These indexes show that items included in the factors: Herding, Prospect, Market, Overconfidence, and Anchoring.

\subsection{Evaluation of Behavioral Factors}

Because 6-point scales are used to measure the impact levels of these variables, the mean values of these variables can decide their impact levels on the investment decision as the following rules:

- Mean values are less than 2 shows that the variables have very low.

- Mean values are from 2 to 3 shows that the variables have low.

- Mean values are from 3 to 4 shows that the variables have moderate.

- Mean values are from 4 to 5 shows that the variables have high.

- Mean values are more 5 shows that the variables have very high. 


\subsection{Impacts of Heuristic Variables on the Investment}

Table 4. Impacts of heuristic variables on the investment

\begin{tabular}{clcc}
\hline Factors & \multicolumn{1}{c}{ Variables } & Mean & Std. Deviation \\
\hline Overconfidence & $\begin{array}{l}\text { X3: You believe that your skills and knowledge of } \\
\text { stock market can help you to outperform the market. }\end{array}$ & 3.66 & 1.15 \\
Anchoring & $\begin{array}{l}\text { X5: You forecast the changes in stock prices in the } \\
\text { future based on the recent stock prices. }\end{array}$ & 3.49 & 1.24
\end{tabular}

Note: Overconfidence has moderate impact (mean $=3.66)$.

As Table 4 shown the individual investors at the HOSE have the degree of confidence at the moderate level. It can be explained that Vietnam security market is emerging so its trend fluctuates complexly. It can go up or down regardless the performances of the listed companies that issue the stocks. For example, during 2006-2007 or 2008-2009, prices of all stocks increased although some companies were not profitable, whereas, recently, stocks of profitable companies continue to decrease. In the discussions of this point, the investors could not predict the market trend and failed to jump into and out of the market timely; they certainly feel less confident of their decisions. This finding does not strongly support the studies of Allen and Evans (2005, p. 108), Gervais, Simon and Odean $(2001$, p. 1) which suggest that people usually believe in their skills and knowledge to outperform the market. It also does not strongly support the studies suggesting that Asian people tend to be more overconfident than European or American people (Yates et al., 1997, p. 94). In other words, the investors at the HOSE need to be more confident to have the effective decisions for their investment.

Anchoring has moderate impact (mean $=3.49$ ).

In terms of anchoring, its moderate impact (mean $=3.49$ ) shows that there are two schools of forecasting the future stock prices for the investment decision making. One of them depends on recent price to forecast future prices while the other is not affected by the recent price. This reflects the status quo of Vietnam market that many people use techniques to analyze and predict the changes of stock prices in the future based on the previous prices while others prefer other information rather the price, which can be available information as stated previously. This can be explained that the high and unexpected fluctuations of stock price trend at the HOSE make the investors to think of the more reliable ways to predict the changes of stock prices than the prices that they experienced in the past.

\subsection{Impacts of Prospect Variables on the Investment}

Table 5. Impacts of Prospect Variables on the investment

\begin{tabular}{clcc}
\hline Factors & \multicolumn{1}{c}{ Variables } & Mean & Std. Deviation \\
\hline & X7: After a prior loss, you become more risk averse. & 3.83 & 1.28 \\
X8: You avoid selling shares that have decreased in value and readily & 3.76 & 1.29 \\
& $\begin{array}{l}\text { sell shares that have increased in value. } \\
\text { X10: You tend to treat each element of your investment portfolio } \\
\text { separately. }\end{array}$ & 4.12 & 1.17 \\
\hline
\end{tabular}

Note: Mental accounting has high impact-highest among prospect variables (mean $=4.12$ ).

As Table 5 shows that among three prospect factors (loss aversion, regret aversion, mental accounting), mental accounting ranks as the variable having the highest impact on the decision making of the investors at the HOSE. This result confirms that investors tend to treat each element of investment portfolio separately.

Loss aversion has moderate impact (mean $=3.83$ ).

In terms of loss aversion, the result demonstrates that to some extent, after a gain, the investors at the HOSE become more risk seeking whereas after a loss, they tend to be more risk averse. These are normal reactions of investors because the prior investment success encourages them so much whereas the failure surely depresses them a lot. However, loss aversion is not always a good strategy because of the principle "high risk-high return". Odean (1998a, p. 1899) also argues that loss aversion may produce bad decisions, which influences investors' 
wealth.

Regret aversion has moderate impact (mean $=3.76)$.

Similar to loss aversion, regret aversion has a moderate effect on the investors at the HOSE. Although the impact is not high, it infers that Vietnamese investors seem to be more willing to sell shares increasing in value than decreasing ones. As an explanation, at a security company asserts that Vietnamese people do not have good investment strategies; moreover, they may not have the acceptable ranges for profit and loss. Many people think that they do not lose until they sell the losing stocks, thus, they refuse to sell them although selling may be the best solution at this time.

\subsection{Impacts of Market Variables on the Investment}

Table 6. Impacts of market variables on the investment

\begin{tabular}{lllc}
\hline Factors & \multicolumn{1}{c}{ Variables } & Mean & Std. Deviation \\
\hline & $\begin{array}{l}\text { X11: You consider carefully the } \\
\text { price changes of stocks that you } \\
\text { intend to invest in. }\end{array}$ & 4.57 & 1.16 \\
X13: Market information is \\
important for your stock \\
investment. \\
X14; You put the past trends of \\
$\begin{array}{l}\text { stocks under your consideration } \\
\text { for your investment. }\end{array}$
\end{tabular}

Note: Market variables-high impacts (mean from 4 to 5 ).

As in the Table 6, market factor has the highest influences on the investment decision of the investors at the HOSE with the means of market variables from 4 to 5 . The individuals tend to consider the information of stock market: general information, past trends of stock price and current stock price changes carefully before making their investment. The standardized deviations of these variables, which are relatively high in comparison to the mean values, show that there may be some investors strongly focusing on the market variables whenever they decide to invest in stocks. In this case, market factor include the market information (about the customers, company's performance, and so on), the price changes of stocks in the market, and the past trends of stocks. These market variables are important to the investors and usually taken under their considerations for the making investment decisions. The high influences of market variables can be linked to the respondents' profiles, which show that most of them have been attended training courses investment. Therefore, they understand the importance of market information to the price movement as well as the importance of technical analysis in forecasting.

\subsection{Impacts of Herding Variables on the Investment}

Table 7. Impacts of herding variables on the investment

\begin{tabular}{|c|c|c|c|}
\hline Factors & Variables & Mean & $\begin{array}{l}\text { Std. } \\
\text { Deviation }\end{array}$ \\
\hline \multirow{3}{*}{ Herding } & X16: Other investors' decisions of the stock volume have impact on your investment decisions. & 3.49 & 1.14 \\
\hline & $\begin{array}{l}\text { X17: Other investors' decisions of buying and selling stocks have impact on your investment } \\
\text { decisions. }\end{array}$ & 3.46 & 1.07 \\
\hline & $\begin{array}{l}\text { X18: You usually react quickly to the changes of other investors' decisions and follow their } \\
\text { reactions to the stock market. }\end{array}$ & 3.95 & 1.05 \\
\hline
\end{tabular}

Note: Herding variables-moderate impacts (mean from 3 to 4).

As in the Table 7, it is found that the herding variables' impact on the investors at the HOSE, which is assumed high, is moderate only. This finding does not strongly support the researches of Farber, Nguyen and Vuong (2006, p. 17) and Tran (2007, p. 23-25), which suggest that the herding effect in Vietnam stock market is very strong, especially toward positive return of the market. This moderate impact of herding factor can be explained as Vietnam stock market has been run for over ten years, so that investors may now have more knowledge and skills to make use of different information from different sources before making investment decision; hence, the 
herding effect has been decreased. However, Vietnam stock market has not yet developed and been mature, so that the existence of herding at moderate level is a certain occurrence.

\section{Conclusion}

There are five behavioral factors of individual investors at the Ho Chi Minh Stock Exchange (Luu, 2011): Herding, Market, Prospect, Overconfidence-gamble's fallacy, and Anchoring-ability bias. The herding factor includes behavioral dimensions: following the decisions of the other investors (buying and selling, choice of trading stocks, volume of trading stocks). The market factor consists of dimensions: price changes, market information. The prospect factor consists of dimensions: loss aversion, regret aversion, and mental accounting. The heuristic dimensions are grouped into two factors: overconfidence-gamble's fallacy and anchoring-ability bias. Recommendations given to investors are that they should consider carefully before investment, but should not care too much about the prior loss for later investment. Besides, the investors should not reduce their regret in investment by avoiding selling decreasing stocks and selling increasing ones.

This research is an investigation into individual investors, not institutional investors. The research just chose sample randomly in Ho Chi Minh, not for Ha Noi stock market. It is necessary to have further research studies to confirm the findings of this research with the larger sample size and the more diversity of respondents (Luu, 2012c; Luu, 2013e). The further research studies are also suggested to apply behavioral finance to explore the behavioral factors of institutional investors at the Stock Exchanges of Vietnam. Ethics should also be included into behavioral factors of institutional investors (Luu, 2012b; Luu, 2012d), especially those in industries in which ethics of stakeholders play a crucial role such as healthcare services (Luu, 2012e; Luu, 2012f; Luu, 2012g). The impact of corporate governance (Luu, 2011; Luu, 2012d; Luu, 2013b; Luu, 2013e) and corporate social responsibility (Luu, 2012d; Luu, 2012g; Luu, 2013a; Luu, 2013c) on behavioral factors of institutional investors can attract researchers as well. The relationship between behavioral factors of institutional investors and marketing effectiveness and brand performance can be another interesting research avenue (Luu, 2012a; Luu, 2012g; Luu, 2013f; Luu, 2012i). Behaviors of institutional investors as an important stakeholder group also can create sense of urgency for higher level of organizational change (Luu, 2012f; Luu, 2013d) and learning (Luu, 2012h; Luu, 2013g).

\section{References}

Ali, N. A., Zairi, M., \& Mahat, F. (2006). Quality HR-TQM Model in Service Context. Staff paper, University of Putra Malaysia.

Allen, D. W., \& Evans, A. D. (2005). Bidding and overconfidence in experimenting financial markets. Journal of Behavioral Finance, 6(3), 8-120. http://dx.doi.org/10.1207/s15427579jpfm0603_1

Barber, B., \& Odean, T. (2001). Boys will be boys: gender, overconfidence, and common stock investment. The Quarterly Journal of Economics, 116(1), 261-292. http://dx.doi.org/10.1162/003355301556400

Barberis, N., \& Huang, M. (2001). Mental Accounting, Loss Aversion, and Individual Stock Returns. The Journal of Finance, 56(4), 1247-1292. http://dx.doi.org/10.1111/0022-1082.00367

Barberis, N., \& Thaler, R. (2003). A survey of behavioral finance. In Constantinides, G., Harris, M., \& Stulz, R. (Eds.), Handbook of the Economics of Finance. Amsterdam: North-Holland.

Bryman, A., \& Bell, E. (2007). Business Research Methods (2nd ed.). Oxford University Press.

Bryman, A., \& Bell, E. (2011). Business Research Methods (3rd ed.). Oxford University Press.

Caparrelli, F. D., Arcangelis, A. M., \& Cassuto, A. (2004). Herding in the Italian stock market: a case of behavioral finance. Journal of Behavioral Finance, 5(4), 222-230. http://dx.doi.org/10.1207/s15427579jpfm0504_5

Chen, G., Kim, K. A., Nofsinger, J. R., \& Rui, O. M. (2007). Trading performance, disposition effect, overconfidence, representativeness bias, and experience of emerging market investors. Journal of Behavioral Decision Making, 20(4), 425-451. http://dx.doi.org/10.1002/bdm.561

Coval, J., \& Shumway, T. (2000). Do behavioral biases affect prices? Working Paper. University of Michigan, Ann Arbor, MI.

Croushore, D. (2006). Money and Banking: A Policy oriented approach. Cengage Learning.

DeBondt, W. F. M., \& Thaler, R. H. (1995). Financial Decision-Making in Markets and Firms: A Behavioral Perspective. Handbooks in Operations Research and Management Science, 9(13), 385-410. http://dx.doi.org/10.1016/S0927-0507(05)80057-X 
Evans, D. A. (2006). Subject perceptions of confidence and predictive validity in financial cues. Journal of behavioral Finance, 7(1), 12-28. http://dx.doi.org/10.1207/s15427579jpfm0701_3

Farber, A., Nguyen, V. H., \& Vuong, Q. H. (2006). Policy Impacts on Vietnam Stock Market: A Case of Anomalies and Disequilibria 2000-2006. CEB Working Paper $\mathrm{N}^{\circ}$ 06/005, Université Libre de Bruxelles-Solvay Business School-Centre Emile Bernheim, April, p.25.

Filbeck, G., Hatfield, P., \& Horvath, P. (2005). Risk aversion and personality type. Journal of Behavioral Finance, 6(4), 170-180. http://dx.doi.org/10.1207/s15427579jpfm0604_1

Fisher, C. (2010). Researching and writing a dissertation, an essential guide for business students (3rd ed.). Pearson Eduction Limited.

Fogel, O., \& Berry, T. (2006). The disposition effect and individual investor decisions: the roles of regret and counterfactual alternatives. Journal of Behavioral Finance, 7(2), 107-116. http://dx.doi.org/10.1207/s15427579jpfm0702_5

Fromlet, H. (2001). Behavioral Finance-Theory and Practical Application. Business Economics, 36(3).

Genesove, D., \& Mayer, C. (2001). Loss aversion and seller behavior: evidence from the housing market. Quarterly Journal of Economics, 116(4), 1233-1260. http://dx.doi.org/10.1162/003355301753265561

Ghauri, P., \& Gronhaug, K. (2010). Research methods in business studies (4th ed.). Great Britain: Pearson Education Limited.

Goodfellow, C., Bohl, M. T., \& Gebka, B. (2009). Together we invest? Individual and institutional investors' trading behaviour in Poland. International Review of Financial Analysis, 18(4), 212-221. http://dx.doi.org/10.1016/j.irfa.2009.03.002

Grinblatt, M., \& Han, B. (2001). The disposition effect and momentum. Working Paper. University of California, Los Angeles, CA.

Hair, J. F., Black, B., Babin, B., Andersion, R. E., \& Tatham, R. L. (1998). Multivariate data analysis. Prentice-Hall, International, Inc.

Helms, J. E., Henze, K. T., Sass, T. L., \& Mifsud, V. A. (2006). Treating Cronbach's Alpha Reliability Coefficients as Data in Counseling Research. The counseling psychologist, 34(5), 630-660. http://dx.doi.org/10.1177/0011000006288308

Hvide, H. K. (2002). Pragmatic beliefs and overconfidence. Journal of Economic Behavior \& Organization. 48(1), 15-28. http://dx.doi.org/10.1016/S0167-2681(01)00221-9

Jaswani, T. (2008). Function And Purpose of Stock Market. Retrieved from http://www.articlesbase.com/investing-articles/function-and-purpose-of-stock-market-582881.html

Kahneman, D., \& Tversky, A. (1979). Prospect theory: an analysis of decision-making under risk. Econometrica, 47(2), 263-291. http://dx.doi.org/10.2307/1914185

Kallinterakis, V., Munir, N., \& Markovic, M. R. (2010). Herd Behavior, Illiquidity, and Extreme Market States: Evidence from Banja Luka. Journal of Emerging Market Finance, 9(3), 305-324. http://dx.doi.org/10.1177/097265271000900303

Kempf, A., \& Ruenzi, S. (2006). Status quo bias and the number of alternatives: an empirical illustration from the mutual fund industry. Journal of Behavioral Finance, 7(4), 204-213. http://dx.doi.org/10.1207/s15427579jpfm0704_3

Kim, K., \& Nofsinger, J. (2008). Behavioral finance in Asia. Pacific-Basin Finance Journal, 16(1-2), 1-7. http://dx.doi.org/10.1016/j.pacfin.2007.04.001

Lai, M. (2001). Are Malaysian investors rational? Journal of Psychology and Financial Markets, 2(4), 210-215. http://dx.doi.org/10.1207/S15327760JPFM0204_5

Leech, N., Barrett, K., \& Morgan, G. (2005). SPSS for intermediate statistics: use and interpretation. Lawrence Erlbaum Associates, Inc.

Lehenkari, M., \& Perttunen, J. (2004). Holding onto the losers: finish evidence. The Journal of Behavioral Finance, 5(2), 116-126. http://dx.doi.org/10.1207/s15427579jpfm0502_5

Liu, Y., Wu, A. D., \& Zumbo, B. D. (2010). The Impact of Outliers on Cronbach's Coefficient Alpha Estimate of Reliability: Ordinal/Rating Scale Item Responses. Educational and Psychological Measurement, 70(1), 


\section{5-21. http://dx.doi.org/10.1177/0013164409344548}

Liua, Y., \& Salvend, G. (2009). Effects of measurement errors on psychometric measurements in ergonomics studies: Implications for correlations, ANOVA, linear regression, factor analysis, and linear discriminate analysis. Ergonomics, 52(5), 499-511. http://dx.doi.org/10.1080/00140130802392999

Luu, T. T. (2010). Organisational culture, leadership and performance measurement integratedness. International Journal of Management and Enterprise Development, 9(3), 251-275. http://dx.doi.org/10.1504/IJMED.2010.037066

Luu, T. T. (2011). Organisational culture and trust as organisational factors for corporate governance. International Journal of Management and Enterprise Development, 11(2), 142-162.

Luu, T. T. (2012a). Marketing effectiveness and its precursors. Asia Pacific Journal of Marketing and Logistics, 24(1), 125-152. http://dx.doi.org/10.1108/13555851211192731

Luu, T. T. (2012b). The linkages among leadership, trust, and business ethics. Social Responsibility Journal, 8(1), 133-148. http://dx.doi.org/10.1108/17471111211196629

Luu, T. T. (2012c). What trust grows through upward influence? Asia-Pacific Journal of Business Administration, 4(2), 158-181. http://dx.doi.org/10.1504/IJMED.2010.037066

Luu, T. T. (2012d). Corporate social responsibility, ethics, and corporate governance. Social Responsibility Journal, 8(4), 547-560. http://dx.doi.org/10.1108/17471111211272110

Luu, T. T. (2012e). Saigon Eye Hospital: An innovative business model in healthcare. Leadership in Health Services, 25(2), 123-138. http://dx.doi.org/10.1108/17511871211221046

Luu, T. T. (2012f). From unbalanced to balanced: performance measures in a Vietnamese hospital. Leadership in Health Services, 25(4), 288-305. http://dx.doi.org/10.1108/17511871211268937

Luu, T. T. (2012g). Corporate social responsibility, leadership, and brand equity in healthcare service. Social Responsibility Journal, 8(3), 347-362. http://dx.doi.org/10.1108/17471111211247929

Luu, T. T. (2012h). Behind knowledge transfer. Management Decision, 50(3), 459-478. http://dx.doi.org/10.1108/00251741211216232

Luu, T. T. (2012i). Behind brand performance. Asia-Pacific Journal of Business Administration, 4(1), 42-57. http://dx.doi.org/10.1108/17574321211207962

Luu, T. T. (2013a). The role of CSR in clinical governance and its influence on knowledge sharing. Clinical Governance: An International Journal, 18(2), 90-113. http://dx.doi.org/10.1108/14777271311317891

Luu, T. T. (2013b). Emotional intelligence as the departure of the path to corporate governance. Corporate Governance, 13(2), 148-168. http://dx.doi.org/10.1108/14720701311316634

Luu, T. T. (2013c). Corporate social responsibility, upward influence behavior, team processes and competitive intelligence. Team Performance Management, 19(1/2), 6-33.

Luu, T. T. (2013d). Underneath organizational health and knowledge sharing. Journal of Organizational Change Management, 26(1), 139-168. http://dx.doi.org/10.1108/09534811311307950

Luu, T. T. (2013e). What can corporate governance build in shipping companies? International Journal of Shipping and Transport Logistics, 5(2), 113-136.

Luu, T. T. (2013f). Competitive intelligence and other levers of brand performance. Journal of Strategic Marketing, 1-23.

Luu, T. T. (2013g). Leading to learning and competitive intelligence. Learning Organization, 20(3), 216-239. http://dx.doi.org/10.1108/09696471311328460

Neuman, W. L., \& Kreuger, L. W. (2003). Social Work Research Methods: Quanlitative and Quantitative applications (1st ed.). United State of America: Pearson Education.

Nevins, D. (2003). Goals-based Investing: Integrating Traditional and Behavioral Finance. SEI Wealth Network.

Nunnally, J. C. (1978). Psychometric theory. New York: McGraw-Hill.

Oberlechner, T., \& Osler, C. L. (2004). Overconfidence in currency markets. Retrieved from http://faculty.haas.berkeley.edu/lyons/Osler\%20overconfidence\%20in\%20FX.pdf 
O'Brien, K. (2007). Factor Analysis: An Overview in the Field of Measurement. Physiotherapy Canada, 59(2), 142-155. http://dx.doi.org/10.3138/ptc.59.2.142

Odean, T. (1998a). Volume, volatility, price and profit when all trades are above average. Journal of Finance, 53(6), 1887-1934. http://dx.doi.org/10.1111/0022-1082.00078

Odean, T. (1999). Do investors trade too much? American Economic Review, 89(5), 1279-1298. http://dx.doi.org/10.1257/aer.89.5.1279

Olsen, R. (1998). Behavioral Finance and Its Implications for Stock-Price Volatility. Investment Management and Research, Financial Analysis Journal, 54(2), 10-18. http://dx.doi.org/10.2469/faj.v54.n2.2161

Pompian, M. (2006). Behavioral Finance and Wealth Management. Wiley Finance, 66-67.

Rabin, M. (2002). Inference by believers in the law of small numbers. Quarterly Journal of Economics, 117(3), 775-816. http://dx.doi.org/10.1162/003355302760193896

Ritter, J. R. (2003). Behavioral Finance. Pacific-Basin Finance Journal, 11(4), 429-437. http://dx.doi.org/10.1016/S0927-538X(03)00048-9

Rockenbach, B. (2004). The behavioral relevance of mental accounting for the pricing of financial options. Journal of Economic Behavior and Organization, 53(4), 513-527. http://dx.doi.org/10.1016/S0167-2681(03)00097-0

Samuel, C. (1996). Stock Market and Investment: The signaling Role of the Market. Policy research working paper No.1612.

Saunders, M., Lewis, P., \& Thornhill, A. (2009). Research methods for business students (5th ed.). Italy: Pearson Education Limited.

Shefrin, H., \& Statman, M. (1994). The disposition to sell winners too early and ride losers too long: theory and evidence. Journal of Finance, 40(3), 777-790. http://dx.doi.org/10.1111/j.1540-6261.1985.tb05002.x

Shelby, L. B. (2011). Beyond Cronbach's Alpha: Considering Confirmatory Factor Analysis and Segmentation. Human Dimensions of Wildlife, 16(2), 142-148. http://dx.doi.org/10.1080/10871209.2011.537302

Shiller, R. J. (1998). Survey evidence on diffusion of interest and information among investors. Journal of Economic Behavior and Organization, 12(1), 47-66. http://dx.doi.org/10.1016/0167-2681(89)90076-0

Shleifer, A. (2000). Inefficient markets: an introduction to behavioral finance. Oxford University Press. Oxford.

Shleifer, A., \& Vishny, R. (1997). The limits of arbitrage. Journal of Finance, 52(1), 35-55. http://dx.doi.org/10.1111/j.1540-6261.1997.tb03807.x

Statman, M. (1999). Behavior finance: past battles and future engagements. Financial Analysts Journal, 55(6), 18-27. http://dx.doi.org/10.2469/faj.v55.n6.2311

Tan, L., Chiang, T. C., Mason, J. R., \& Nelling, E. (2008). Herding behavior in Chinese stock markets: An examination of A and B shares. Pacific-Basin Finance Journal, 16(1-2), 61-77. http://dx.doi.org/10.1016/j.pacfin.2007.04.004

Teweles, R. J., \& Bradley, E. S. (1998). The Stock Market (7th ed.). John Wiley and Sons, Inc.

Thaler, R. H. (1999). The end of behavioral finance. Financial Analysts Journal, 55(6), 12-17. http://dx.doi.org/10.2469/faj.v55.n6.2310

Vuong, D. H. Q. (2011). Tài chính hành VI: Giải thích một số hiện tượng bất thường trên TTCK VN. Retrieved from http://www.saga.vn/Cohoigiaothuong/Thitruong1/Thitruongchungkhoan/20487.saga

Waweru, N. M., Munyoki, E., \& Uliana, E. (2008). The effects of behavioral factors in investment decision-making: a survey of institutional investors operating at the Nairobi Stock Exchange. International Journal of Business and Emerging Markets, 1(1), 24-41. http://dx.doi.org/10.1504/IJBEM.2008.019243

Weber, E. U., \& Hsee, C. K. (2000). Culture and individual judgment and decision making. Applied Psychology, 49(1), 32-61. http://dx.doi.org/10.1111/1464-0597.00005

Yates, J. F., Lee, J., \& Bush, J. G. (1997). General knowledge overconfidence: cross-national variations, response style, and "reality". Organizational Behavior and Human Decision Processes, 70(2), 87-94. http://dx.doi.org/10.1006/obhd.1997.2696

Zuravicky, O. (2005). The Stock Market: Understanding and applying ratios, decimals, fractions, and percentages. The Rosen Publishing Group, Inc. 


\section{Copyrights}

Copyright for this article is retained by the author(s), with first publication rights granted to the journal.

This is an open-access article distributed under the terms and conditions of the Creative Commons Attribution license (http://creativecommons.org/licenses/by/3.0/). 